\title{
Pengembangan Bahan Ajar Pembelajaran Matematika Untuk Mahasiswa PGSD Semester 6
}

\author{
Erna Yayuk \\ ernayayuk17@umm.ac.id \\ PGSD, FKIP, Universitas Muhammadiyah Malang \\ Mathematics Learning Material Development for Student Teachers of Elementary School
in Semester 6
}

\begin{abstract}
The purpose of this study was produce a mathematics learning companion book that was feasible to use and to measure the student's response to the teaching material. This study uses the Research and Development $(R \& D)$ method with a $4 D$ model, which includes needs analysis, design, development, and dissemination. The feasibility was measured with the validity test from material and the design expert. The effectiveness was measured with the test to one class of PGSD FKIP UMM students, then the second test was conducted in 2 classes. The results of the research obtained are the validity values of teaching materials worthed $91.6 \%$, and the validation test the material experts scored $78.8 \%$, all are in 'valid' criteria. The effectiveness of the teaching materials were also shown from positive responses obtained from lecturers and students as product users. After revision, the effectiveness of teaching materials reached $86.93 \%$, in the 'effective' criteria. Lecturers and students concluded that the use of teaching materials companion book was effective for learning
\end{abstract}

Keywords: development of textbooks, mathematics learning

Received date: 3 Januari 2019

Article Info

Revised date: 29 April 2019

Accepted date: 21 Mei 2019

\section{PENDAHULUAN}

Dosen berperan sebagai tenaga pendidik tidak hanya berperan sebagai pemegang tonggak peradaban saja, melainkan juga sebagai pusat peradaban bagi kemajuan bangsa. Dosen adalah sosok yang berperan aktif dalam mendidik anak dengan memberikan berbagai pengalaman, mentranfer ilmu pengetahuan untuk dijadikan bekal yang sangat penting bagi dirinya. Bahkan yang lebih penting, mereka harus mengembangkan dan memperdayakan manusia, untuk dicetak menjadi seorang yang berkarakter dan bermental agar mereka tidak minder dalam menghadapi masalah. Untuk mendukung peran tersebut, salah satunya ditunjang dengan fasilitas dan sumber belajar. Fasilitas dan sumber belajar sangat penting untuk menentukan keberhasilan implementasi kurikulum, yaitu salah satunya kurikulum2013.

Fasilitas dan sumber belajar yang dapat mendukung suksesnya implementasi kurikulum antar lain laboratorium, pusat sumber belajar, perpustakaan, tenaga pengelolaan, dan peningkatan kemampuan dalam mengelolannya. Menurut Eliyawati (2008) fasilitas dan sumber belajar tersebut perlu didayagunakan seoptimal mungkin, dipelihara dan disimpan dengan sebaik-baiknya. Berbicara tentang sumber belajar salah satunya yang bisa mendukung proses pembelajaran adalah bahan ajar. Dosen dituntut untuk dapat mengembangkan bahan ajar secara mandiri. Ada sejumlah alasan mengapa serang dosen perlu mengembangkan bahan ajar, antara lain: ketersediaan bahan sesuai kurikulum, karakteristik sasaran, dan tuntutan pemecahan masalah belajar.

Sebuah bahan ajar bisa menempati posisi sebahgai bahan ajar pokok atau suplemen, hal ini untuk mendukung kurikulum. Bahan ajar pokok adalah bahan ajar yang memenuhi tuntutan kurikulum. Bahan ajar suplemen adalah bahan ajar yang dimaksudkan untuk memperkaya, menambah atau memperdalam isi kurikulum. Oleh karena itu seorang dosen (dosen di Perdosenan Tinggi) harus mampu mengembangkan bahan ajar untuk tercapainya tujuan pembelajaran.

Pembelajaran merupakan kegiatan yang dilakukan untuk menginisiasi, memfasilitasi, ddan meningkatkan intensitas dan kualitas belajar peserta didik (Amri, 2014). Maka untuk memfasilitasi 
kualitas belajar mahasiswa diperlukan kreativitas dosen dalam proses pembelajarannya. Seorang dosen dapat menggunakan bahan ajar sesuai yang sekiranya cocok untuk digunakan dalam proses pembelajaran. Pembelajaran yang dimaksud dalam hal ini adalah pembelajaran matematika.

Pada hakikatnya matematika adalah suatu disiplin ilmu yang muncul dari sebuah pperadaban manusia yang sangat panjang di bumi ini. Matematika merupakan bagian dari kehidupan manusia (Manfaat, 2010). Matematika sebagai salah satu ilmu dasar, dewasa ini telah berkembang pesat baik materi maupun kegunaannya dalam kehidupan sehari-hari. Penggunaan matematika secara baik sejak dini perlu ditanamkan sehingga konsep-konsep dasar matematika dapat diterapkan dengan tepat dalam kehidupan sehari-hari. Dengan memakai memakai konsep dasar matematika maka anak akan memiliki bekal untuk mengikuti perkembangan ilmu dan teknologi yang berkembang pesat dewasa ini.

Lebih lanjut Soejono (dalam Giri, 2013) mengemukakan bahwa pentingnya belajar matematika tidak lepas dari peran matematika dalam segala dimensi kehidupan,seperti banyaknya persoalan kehidupan yang memerlukan kemampuan berhitung dan mengukur. Oleh karena itu, pada dasarnya semua orang akan membutuhkan ilmu matematika dalam kehidupan sehari-harinya, hal inlah yang menjadi alasan jika matematika merupakan mata pelajaran yang wajib di sekolah.

Dalam pembelajaran matematika tentunya tidak lepas dari ciri matematika itu sendiri, yaitu memiliki objek kejadian yang abstrak, berpola pikir deduktif dan konsisiten. Disamping itu matematika berfungsi untuk mengembangkan kemampuan berkomunikasi dengan menggunakan bilangan dan simbol-simbol serta ketajaman penalaran yang dapat membantu memperjelas dan menyelesaikan permasalahan dalam kehidupan sehari-hari.

Berdasarkan teori-teori yang telah disampaikan diatas, dan berdasarkan hasil observasi semester Ganjil 2017/2018, didapatkan data sekaligus informasi pembelajaran matematika SD, bahwa ada beberapa fakta yang menyatakan : (1) $90 \%$ mahasiswa PGSD kelas V D-F tidak ada yang mempunyai literatur buku, meskipun dosen sudah menghimbau untuk cari beberapa referensi yang bisa menunjang perkuliahan; (2) Mahasiswa hanya berpegang pada Handout dari dosen; (3) 73\% mahasiswa kurang memahami materi karena ativitas yang dilakukan, mendengarkan, melihat, dan mencontoh tetapi kreativitas kurang sehingga pembelajaran jadi kurang bermakna; (4) Mahasiswa yang mencapai nilai ketuntasan dalam Ujian Tengah Semester (UTS) sebesar 47\%; (5) dosen merasa kesulitan dalam melakukan pembelajaran terutama ketika mencakup 3 aspek yaitu keterampilan, afektif (spritual dan sosial) dan kognitif.

Berdasarkan kondisi diatas, terlihat bahwa proses pembelajaran terlihat kurang berjalan optimal. Salah satu upaya untuk mengatasi tersebut adalah dengan menyediakan salah satu sumber belajar yang sesuai dengan kebutuhan mahasiswa yaitu dengan dikembangkannya buku pendamping pembelajaran matematika. Buku ini direncanakan berbeda dengan buku-buku yang sudah ada. Pada umumnya buku yang sudah ada hanya memuat aspek kognitif sehingga mahasiswa terkesan hanya sebagai seorang penghafal, akan tetapi buku yang akan dikembangkan ini diarahkan pada tiga aspek yaitu aspek afeksi, psikomotorik, dan kognitif. Selain itu, buku ini bersifat interaktif, berbasis aktivitas, dan inspiratif sehingga proses pembelajaran matematika akan menyenangkan, menantang dan memotivasi mahasiswa untuk berpartisipasi aktif serta memberikan ruang yang cukup prakarsa, kreativitas, kemandirian.

Rencana pengembangan buku pendamping ini didukung hasil penelitian Fawaid (2015) yang berjudul pengembangan buku pendamping dosen berbasis kurikulum 2013 mata pelajaran matematika kelas VII semester 1. Hasil penelitian ini menunjukkan kualitas buku pendamping dosen matematika SMP kelas VII berbasis kurikulum 2013 berkualitas baik.

Oleh karena itu, untuk memudahkan mahasiswa dalam memahami materi dan meningkatkan motivasi pembelajaran matematika peneliti berupaya untuk mengembangkan bahan ajar matematika dan mengambil judul penelitian " Pengembangan Buku Pendamping Pembelajaran Matematika Untuk Mahasiswa PGSD”

\section{KAJIAN PUSTAKA Pengertian Bahan Ajar}

Bahan jar merupakan seperangkat alat pembelajaran yang disusun secara sistematis yang berisikan materi pembelajaran, metode, strategi, pendekatan, batasan-batasan dan cara mengevaluasiyang didesain secara sistematis dan menarik dalam rangka mencapai tujuan yang 
diharapkan, yaitu mencapai Capain pembelajaran Lulusan, Sub Capaian pembelajaran mata kuliahdalam segala kompleksitasnya. Pengertian ini menggambarkan bahwa suatu bahan ajar hendaknya di rancang dan di tulis dengankaidak intruksional dan sesuai kurikulum yang ada karena akan digunakan oleh mahasiswa sebagai calon guru untuk membantu dan menunjang proses pembelajaran. Dengan adanya bahan ajar ini dharapkan mahasiswa mampu mmbelajarkan materi matematika secara runtut kepada susiswa dantercapai seluruh kompetensi yang telah ditentukan. Bahan ajar ini tidak hanya memuat materi yang berisi tentang pengetahuan, tetapi juga terkait dengan keterampilan dan sikap yang perlu dipelajari siswa .

Beberapa bentuk buku ajar yang digunakan di sekolah maupun perguruan tinggi yaitu buku refrensi, modul, diktat, bahan ajar. Berdasarkan pedoman penulisan buku ajar yang dikeluarkan oleh Direktorat Pendidikan Dasar dan Menengah Departemen Pendidikan Nasional Tahun 2013, bahan ajar memiliki beberapa karakteristik, yaitu self Intructional, Self Contained, Stand alone, adaptive, and uses friendly.

Self Intructional yaitu bahan ajar dapat membantu mahasiswa dalam belajar secara mandiri dengan bahan ajar yang telah dikembangkan. Untuk memenuhi karakter self Intructional maka rumusan tujuan harus jelas, baik tujuan akhir maupun tujuan sementara. Self Contained yaitu seluruh materi pelajaran dalam satu unit kompetensi atau sub unit kompetensi yang dipelajari terdapat dalam satu bahan ajar secara utuh. Stand alone artinya bahan ajar yang dikembangkan harus berdiri sendiri tanpa bergantung dari buku ajar yang lain. Adaptive yaitu buku ajar yang dikembangkan seyogyanya memiliki daya adaftif yang tinggi terhadap perkembangan ilmu pengetahuan dan teknologi. uses friendly adalah setiap intruksi yang adda pada bahan ajar dapat terpahami dengan mudah bagi penggunanya (Arum, Wahyudi.2016).

Secara garis besar, fungsi dari bahan ajar bagi mahasiswa sebagai calon guru adalah untuk mengarahkan semua aktivitasnya dalam proses pembelajaran sekaligus merupakan substansi kompetensi yang seharusnya diajaran kepada siswa. Bahan ajar juga berfungsi sebagai alat evaluasi pembelajaran. Berdasarkan strategi pembelajaran bahan ajar memiliki fungsi yang dapat dibedakan menjadi tiga, yaitu fungsi pembelajaran klasikal, Individual dan kelompok (Lestari, 2013)..

1. Fungsi Klasikal; Buku ajar memiliki fungsi sebagai sumber informasi, pengawas, pengendali serta sebagai pendukung proses pembelajaran

2. Fungsi Individual, Secara individual bahan jar sebagai media dan alat untuk menyusun dan mengawasi mahasiswa ddalam memperoleh informasi

3. Fungsi Kelompok; Secara klasikal bahwa bahan ajar memiliki fungsi sebagai bahan yang terintegrasi dalam pelaksanaan pembelajaran kelompok, sebagai pendudkung bahan ajar utama, dan apabila di rancang sedemikian rupa maka dapat meningkatkan motivasi belajar

Pembelajaran matematika merupakan pembelajaran yang dikaitkan dalam kehidupan seharihari. Sujono (1988:5) Matematika merupakan ilmu pengetahuan tentang penalaran yang logik dan masalah yang berhubungan dengan bilangan. Pramudita dan Anugraheni $(2017,71)$ berpendapat bahawa matematika merupakan salah satu cabang ilmu yang menerapkan logika dalam proses berfikirnya. Suherman dkk (2003:16) Matematika adalah ilmu pengetahuan yang diperoleh dengan bernalar. Pendapat di atas menjelaskan bahwa matematika merupakan ilmu pengetahuan yang diberikan kepada mahasiswa sebagai salah satu matakuliah yang berkaitan dengan penalaran dan berhubungan dengan bilangan yang berkaitan dengan konsep algoritma yang luwes, akurat, efisien, dan tepat dalam pemecahan masalahnya. Sehingga mahasiswa dapat membuahkan hasil belajar berupa perubahan pengetahuan menghitung, dan hal ini sangat bermanfaat bagi kehidupan anak sehari-hari

Pembelajaran matematika SD merupakan salah satu matakuliah yang diberikan untuk membekali mahasiswa sebagai calon guru yang memiliki kompetensi dasar yaitu kompetensi pedagogik, kompetensi profesional, kompetensi sosial dan kompetensi kepribadian. Selain itu matakuliah ini diharapkan dapat membantu mahasiswa merancang pembelajaran matematika yang baik sesuai karakteristik siswa SD (Lasmiyati 2014).

\section{METODE PENELITIAN}

Penelitian ini menggunakan pendekatan kualitatif dan jenis penelitian adalah Penelitian dan Pengembangan (Research \& Development/R\&D) yaitu penelitian yang digunakan untuk menghasilkan produk tertentu dan menguji kefektifan produk tersebut. 
Tahap pertama, studi pendahuluan dilakukan dengan menerapkan pendekatan deskriptif kualitatif. Kedua, tahap pengembangan desain model dengan menerapkan pendekatan deskriptif, dilanjutkan dengan penerapan ujicoba terbatas desain model dengan menerapkan metode eksperiment (Single one shot Case Study). Setelah ada perbaikan dari uji terbatas, maka dilanjutkan dengan uji yang lebih luas dengan metode eksperiment (one group pretes-postest).

Subyek penelitian ini adalah mahasiswa PGSD semester 6 Angkatan 2016 yang menempuh matakuliah pembelajaran matematika sebanyak 43. Lokasi penelitian secara purposif yaitu dipilih dengan sengaja karena sesuai dengan penelitian yaitu di PGSD FKIP Malang sebagai prodi yang menyelenggarakan pendidikan untuk calon dosen sekolah dasar, yang telah secara konsisten melaksanakan program Pendidikan. Pemilihan tempat penelitian juga dilakukan secara purposive, yaitu dipilih kelas A (uji terbatas) sebanyak 43 mahasiswa, yang secara kapability mampu secara praktis melaksanakan pembelajaran matematika dengan menggunakan buku pendamping pembelajaran matematika.

Model pengembangan dalam penelitian pengembangan ini mengikuti desain model 4D (Trianto.;2010). Adapun tahapan penelitian yang akan digunakan sebagai berikut:

1. Analisis kebutuhan, Pada penelitian ini akan dilakukan dengan tahapan awal berangkat dari adanya potensi atau masalah yangterjadi di lapang yaitu kelas pembelajaran matematika mahasiswa PGSD. Selanjutnya setelah potensi dan masalah dapat ditunjukkan secara faktual dan uptode, maka selanjutnya perlu dikumpulkan berbagai informasi yang dapat digunakan sebagai bahan perencanaan produk pengembangan buku pendamping pembelajaran matematika yang diharapkan dapat mengatasi masalah tersebut.

2. Desain Produk. Dalam penelitian ini peneliti akan menghasilkan buku pendamping pembelajaran matematika, maka dari itu peneliti membuat rancangan desain buku baru. Rancangan buku baru ini dibuat berdasarkan penilaian terhadap buku lama, yang telah dipakai di dalam kelas beserta aktivitas pembelajaran yang dihasilkan sehingga dapat ditemukan kelemahan-kelemahan terhadap buku tersebut. Selain itu peneliti disini juga melakukan penelitian ke buku-buku lain yang dipandang isinya bagus dan dapat menjadi refrensi pembelajaran matematika.

3. Develop, setelah kegiatan desain maka dilakukan proses pengembangan. Selanjutnya sebelum dilakukan uji coba pada kegiatan ini juga dilakukan uji validasi desain, yaitu suatu kegiatan untuk menilai apakah rancangan produk, dalam hal ini buku baru secara rasional akan lebih efektif dari yang lama atau tidak ada. Dikatakan secara rasional, karena validasi di sini masih bersifat penilaian berdasarkan pemikiran rasional, belum fakta lapangan. Dalam kali ini validasi menghadirkan beberapa pakar atau ahli yang sudah pengalaman untuk menilai produk baru yang dirancang tersebut sehingga menghasilkan beberapa kelemahan. Kelemahan tersebut selanjutnya dicoba untuk dikurangi dengan cara memperbaiki desain.

4. Uji Coba, pada tahap ini merupakan tahap penggunaan perangkat yang telah dikembangkan pada skala yang lebih luas dan tujuan lain dari penelitian ini adalah untuk mengetahui efektifitas penggunaan produk yang dikembangkan dalam kegiatan elajar mengajar.

Teknik pengumpulan data dalam penelitian ini menggunakan 3 metode dimana metode tersebut digunakan secara simultan dan saling melengkapi satu sama lain. Adapun metode yang digunakan adalah sebagai berikut: a) Wawancara, teknik ini digunakan untuk mendapatkan informasi awal mengenai analisis kebutuhan Mahasiswa semester 6 Angkatan 2016 yang sedang menempuh Pembelajaran Matematika. b) Angket, angket ini digunakan untuk mengetahui hasil validasi baik dari ahli bahan ajar, ahli materi, ahli pembelajaran, ahli produk. Selain itu juga angket digunakan untuk mengetahui minat mahasiswa sebelum dikembangkan bahan ajar matematika ini dan untuk mengukur respon mahasiswa semester 6 Angkatan 2016 ketika proses pembelajaran digunakan dengan memanfaatkan bahan ajar pembelajaran matematika. c) Penugasan, penugasan ini dipakai untuk melihat tingkat kefektifan dari penggunaan proses pembelajaran yang dilakukan sebelum dan sesudah proses pembelajaran memakai buku pendamping pembelajaran. d) Observasi, digunakan untuk mengamati proses pembelajaran matematika mahasiswa semester 6 Angkatan 2016 sebelum menggunakan buku ajar matematika dan pada saat ujicoba buku ajar matematika yang telah dikembangkan.

Instrumen dalam penelitian ini sesuai dengan teknik yang telah digunakan yaitu (1) Pedoman wawancara, berisi tentang kisi-kisi pertanyaan tentang proses pembelajaran ketika menggunakan buku pendamping pembelajaran matematika, (2) Angket, berisi tentang aspek respon mahasiswa maupun dosen ketika menggunakan bahan ajar matematika (3) Soal penugasan, berisi tentang soal-soal yang 
tercover di dalam buku pendamping, Hal ini digunakan untuk mengukur tingkat pemahaman mahasiswa dalam menguasai materi matematika. (4) lembar observasi, berisi tentang deskripsi pengembangan buku pendamping beserta hasil ujicoba ketika dilaksanakan di kelas,

Dalam penelitian pengembangan ini akan dilakukan teknik analisis data sebagai berikut: 1) Secara kulitatif. Teknik analisa secara kualitatif ini digunakan untuk menganalisa pada saat tahap studi pendahuluan. Selain itu analisa data ini digunakan untuk menganalisi data kualitatif yang diperoleh dari uji validasi ahli ahli bahan ajar, ahli materi, ahli pembelajaran,ahli produk. 2) Secara Kuantitatif. Analisis data kuantitatif ini dipakai untuk menganalisis data yang diperoleh pada saat ujicoba. Uji coba pada penelitian ini akan dilakukan dengan pengujian melalui dua tahap yaitu uji terbatas dan pengujian yang lebih luas: a) Pengujian terbatas dilakukan pada mahasiswa PGSD kelas A dengan dua kali pengujian, yaitu ujicoba 1, ujicoba 2. Metode eksperiment model Single one shot Case Study. b) Pengujian yang lebih luas. Pengujian model yang lebih luas dilakukan pada kelas B dan C dengan desain one group pretest-postest.

\section{HASIL PENELITIAN DAN PEMBAHASAN}

Penelitian pengembangan ini dilakukan untuk menghasilkan sebuah produk yang berbentuk Buku Pendamping Pembelajaran Matematika untuk Mahasiswa PGSD sebagai upaya peningkatan kompetensi dosen dalam melakukan pembelajaran di PGSD. Pada penelitian ini menggunakan beberapa tahapan proses pengembangan produk model $4 \mathrm{D}$. Adapun langkah tersebut adalah sebagai berikut:

\section{Need Assesment (Analisis Kebutuhan)}

Berdasarkan hasil observasi kepada mahasiswa PGSD diperoleh informasi awal data yang menyatakan tentang kondisi proses pembelajaran di sana dan kebutuhan mahasiswa. Adapun hasilnya dapat dilihat pada tabel berikut ini:

Tabel 4.1 Hasil Analisis Kebutuhan Malang Melalui Hasil Wawancara

\begin{tabular}{|c|c|c|}
\hline No & Pertanyaan & Temuan \\
\hline & Mahasiswa & \\
\hline 1 & $\begin{array}{l}\text { Jumlah dan karakteristik } \\
\text { mahasiswa kelas A, B, C }\end{array}$ & $\begin{array}{l}\text { Jumlah mahasiswa kurang lebih } 43 \text {, dan karakteristiknya } \\
\text { bermacam-macam baik dari segi kemampuan, gender, latar } \\
\text { belakang maupun minat mahasiswa. }\end{array}$ \\
\hline 2 & $\begin{array}{lr}\text { Aktivitas } & \text { mahasiswa } \\
\text { dalam } & \text { Pembelajaran } \\
\text { Matematika } & \text { dan rata-rata }\end{array}$ & $\begin{array}{l}\text { Aktivitas mahasiswa tergolong sedang, artinya } 53,49 \% \\
\text { dari } 43 \text { mahasiswa dominan aktif tetapi } 46,51 \% \text { mahasiswa } \\
\text { masih ditunjuk oleh dosen . }\end{array}$ \\
\hline 3 & $\begin{array}{l}\text { kemampuan mahasiswa } \\
\text { Buku yang digunakan } \\
\text { mahasiswa dalam proses } \\
\text { pembelajaran selama ini }\end{array}$ & $\begin{array}{l}\text { Modul Pembelajaran Matematika PJJ, Fotokopi Buku } \\
\text { Matematika dari perpustakaan dan refrensi dari google. }\end{array}$ \\
\hline 4 & $\begin{array}{lr}\text { Minat mahasiswa } & \text { dalam } \\
\text { penggunaan } & \text { buku } \\
\text { matematika } & \text { yang } \\
\text { digunakan } & \end{array}$ & $\begin{array}{l}\text { Sejauh ini minat mahasiswa masih cukup, namun jika } \\
\text { terlalu lama untuk membaca terkadang anak jadi malas dan } \\
\text { bosan, bahkan } 37,20 \% \text { mahasiswa hanya mengandalkan } \\
\text { fotokopi dari buku yang ada, dan yang lain tidak punya } \\
\text { refrensi }\end{array}$ \\
\hline 5 & $\begin{array}{l}\text { Kemampuan mahasiswa } \\
\text { memahami materi ketika } \\
\text { menggunakan buku } \\
\text { tersebut }\end{array}$ & $\begin{array}{l}\text { Mahasiswa yang dominan dan yang gemar membaca buku } \\
\text { sangat aktif akan tetapi yang tidak terbiasa membaca } \\
\text { ditanya dosen tentang materi yang ada mudah lupa dan sulit } \\
\text { untuk dipahami }\end{array}$ \\
\hline 1 & $\begin{array}{l}\text { Dosen } \\
\text { Kemampuan dosen dalam } \\
\text { mengajar menggunakan } \\
\text { buku matematika }\end{array}$ & $\begin{array}{l}\text { Emampuan dosen sudah bagus materi yang ada dibuku } \\
\text { apat tersampaikan semuanya }\end{array}$ \\
\hline 2 & $\begin{array}{l}\text { Kendala yang dihadapi } \\
\text { saat penggunaaan buku } \\
\text { matematika tersebut yang } \\
\text { digunakan }\end{array}$ & $\begin{array}{l}\text { Dosen terkadang merasa bahwa anak-anak sulit untuk } \\
\text { dikondisikan ketika disuruh membaca buku, mereka tidak } \\
\text { fokus bahkan ada yang tidak mendengarkan perintah }\end{array}$ \\
\hline
\end{tabular}




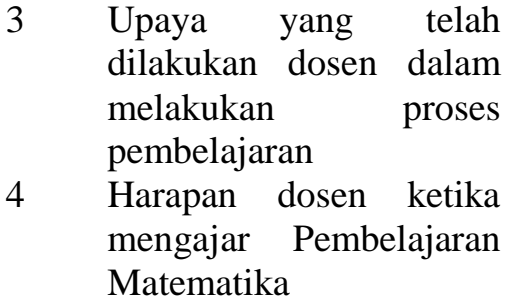

3 Upaya yang telah dilakukan dosen dalam pembelajaran Matematika dosen, ngobrol dengan teman sebangku atau dengan sebelahnya

Dosen memakai trik dengan Yel-yel supaya anak memperhatikan dan diam mendengarkan intruksi dosen, dalam mengajar dosen pun berupaya untuk bisa membuat kontekstual dari materi matematika yang bersifat abstrak Dosen berharap bisa menciptakan pembelajaran yang bisa menarik bagi mahasiswa, dan mereka mudah memahami materi tidak sekedar menghafal

Berdasarkan hasil wawancara dari kegiatan analisis kebutuhan yang dilakukan diatas, dapat disimpulkan bahwa dosen dalam mengajar Pembelajaran Matematika selama ini dengan menggunakan buku matematika PJJ dari pemerintah belum berjalan maksimal dan masih ditemukan beberapa kendala. Kemampuan dalam pemahaman materi juga terkategori belum sepenuhnya diterima mahasiswa dengan baik, hanya beberapa mahasiswa saja dominan yang memang tergolong aktif dan pintar. Rata-rata minat mahasiswa saat menggunakan buku matematika tersebut terkadang naik-turun dimungkinkan karena bahan ajar tersebut kurang menarik, maka dari itu dibutuhkan bahan ajar yang mampu memahamkan mahasiswa pada materi dengan baik dan juga membangkitkan motivasi mahasiswa.

Tabel 4.2 Hasil Analisis Kebutuhan di prodi PGSD Melalui Hasil Observasi

\begin{tabular}{|c|c|c|c|}
\hline No & Aspek pengamatan & Ya & Tidak \\
\hline 1 & $\begin{array}{l}\text { Kurikulum pembelajaran yang diterapkan adalah Kurikulum Perguruan } \\
\text { Tinggi (KPT) }\end{array}$ & $\mathrm{v}$ & \\
\hline 2 & Ketersediann buku di Program Studi cukup memadai & $\mathrm{v}$ & \\
\hline 3 & $\begin{array}{l}\text { Mahasiswa memiliki antusias yang tinggi terhadap proses Pembelajaran } \\
\text { Matematika yang diterapkan dosen }\end{array}$ & & $\mathrm{v}$ \\
\hline 4 & Pembelajaran Matematika yang diterapkan menggunakan berbagai model & $\mathrm{v}$ & \\
\hline 5 & $\begin{array}{l}\text { Buku matematika yang di pakai dosen dapat mengaktifkan mahasiswa dalam } \\
\text { pembelajaran }\end{array}$ & & $\mathrm{v}$ \\
\hline 6 & Buku matematika memudahkan mahasiswa dalam memahami materi & & $\mathrm{v}$ \\
\hline 7 & Buku matematika mampu membuat mahasiswa menjadi kreatif & & $\mathrm{v}$ \\
\hline 8 & $\begin{array}{l}\text { Buku matematika membantu membangkitkan interaksi mahasiswa dengan } \\
\text { mahasiswa yang lainnya dan antara mahasiswa dengan dosen }\end{array}$ & & $\mathrm{v}$ \\
\hline 10 & Semua mahasiswa mengikuti proses Pembelajaran Matematika & & \\
\hline
\end{tabular}

Berdasarkan hasil wawancara dan observasi diatas menunjukkan bahwa Pembelajaran Matematika selama ini yang diterapkan belum sepenuhnya berjalan optimal. Hal ini terlihat dari beberapa indikator yaitu buku matematika yang tersedia di sekolah dari sisi jumlah sudah cukup memadai namun antusias mahasiswa terhadap Pembelajaran Matematika masih kurang. Mahasiswa ketika diajar dosen sebagian yang tidak memperhatikan, mereka memilih mengobrol dengan teman sebangku bahkan ada yang buka Hp meskipun sudah dikondisikan untuk memasukkan di tas, hal ini sering dilakukan ketika proses pembelajaran.

Di langkah pembelajaran dosen sudah berusaha menerapkan model pembelajaran PAIKEM, namun mahasiswa dalam belajar kurang kreatif dan kurang membangkitkan interaksi mahasiswa dan dosen. Ada 2 orang terlihat dominan sangat aktif dan kreatif. Hal ini diperkuat dari hasil FGD bahwa anak-anak ketika menggunakan buku mahasiswa terkesan masih menghafal, budaya membaca dari mahasiswa juga nampak kurang.

\section{Design (Perencanaan)}

Pada tahap kedua ini dilakukan perencanaan dengan menentukan produk yang akan dikembangkan yaitu buku Pendamping Matematika yang Menyenangkan dengan langkah pertama yaitu menentukan isi materi yang sesuai jika digunakan untuk Pembelajaran Matematika, dengan memilih subjek uji coba produk pada mahasiswa kelas A,B,C pada saat Pembelajaran Matematika berlangsung. Setelah itu menetapkan CPL, CPMK dan Sub CPMK. Dalam merencanakan pengembangan buku dalam satu semester ini. 
Langkah berikutnya yaitu pengembangan produk awal yang merupakan pembuatan produk sebelum dilakukannya proses validasi kepada ahli bahan ajar, ahli materi dan ahli pembelajaran. Pada tahap ini merupakan tahap penting yaitu bagaimana cara menyusun sistematika buku yang benar. Dimulai dari merancang sampul kemudian menentukan materi sesuai yang dipilih

\section{Develoop (Pengembangan)}

Pada tahap pengembangan ini dilakukan proses validasi. Validasi dilakukan untuk menguji kevalidan atau kelayakan produk yang dikembangkan. Baik dari segi tampilan, materi, kesesuaian dengan model dan lain sebagainya yag menyangkut syarat pembuatan buku. Validasi dilakukan oleh beberapa validator yang merupakan ahli dalam bidang bahan ajar beruba buku ini.

Proses validasi dilakukan dalam dua kali tahapan, sehingga dalam penelitian ini akan ada jenis data yang diperoleh yaitu validasi pertama dimana validasi dilakukan setelah dikembangkannya produk dan validasi kedua yaitu validasi yang dilakukan setelah melakukan revisi produk yang dilakukan atas kritik dan saran serta penilaian angket. Berikut ini paparan tentang hasil validasi:

\section{a. Validasi Ahli Bahan Ajar}

Validasi tahap I ini dilakukan dengan menetukan validator ahli bahan ajar berupa buku pendamping matematika yaitu bapak Ari Dwi Haryono, M.Pd. Validasi buku dinilai dengan beberapa aspek penilaian yaitu: komponen buku, Kesesuaian Kegiatan, Kejelasan Petunjuk, Anatomi dan kesesuaian buku dengan materi. Adapun hasil yang diperoleh dari validasi ini adalah sebagai berikut:

1) Validasi bahan ajar tahap I

Setelah pembuatan produk awal selesai, diperoleh masukan dari validator yaitu materi masih belum terstruktur dan ada kegiatan yang tidak saling berhubungan, materi perlu disesuaikan lagi dengan RPS yang dipilih, Layout perlu buat semenarik mungkin. Hasil validasi buku tahap I dapat dilihat pada tabel berikut:

Tabel 4.3 Rekapitulasi Angket Validasi Ahli Bahan Ajar Tahap I

\begin{tabular}{llc}
\hline No & \multicolumn{1}{c}{ Aspek Penilaian } & Hasil Validasi \\
\hline 1 & Buku yang dikembangkan memuat kata pengantar & 3 \\
2 & Memuat daftar isi & 4 \\
3 & Mencantumkan tujuan pembelajaran & 4 \\
4 & Materi sesuai sub CPMK yang dikembangkan & 4 \\
5 & Bahasa yang digunakan sesuai dengan usia mahasiswa & 3 \\
6 & Bahasa yang digunakan komunikatif & 3 \\
7 & Tampilan tek/font dapat dibaca dengan jelas & 2 \\
8 & Desain dampat menarik perhatian mahasiswa & 4 \\
9 & Adanya gambar yang mendukung proses penyerapan materi & 3 \\
10 & Terapat rangkuman dari seluruh materi yang ada & 3 \\
12 & Terdapat latihan soal yang bersifat menantang & 2 \\
& Skor Total & 32 \\
& Skor Maksimal & 48 \\
& Presentase & $66,7 \%$ \\
\hline
\end{tabular}

Hasil validasi seperti tertuang pada tabel diatas diperoleh skor 32 atau 66,7\%. Hal ini menunjukkan bahwa buku yang dikembangkan sudah layak namun masih banyak dilakukan revisi atatu perbaikan. Adapun hasil masukannya adalah jenis dan ukuran huruf yang digunakan sesuai tingkat mahasiswa, soal lebih dibuat menantang tidak hanya soal rutin, Gambar dan yang ditampilkan tidak hanya sekedar melengkapi isi dari buku tersebut tetapi lebih disesuaikan dengan materi.

2) Validasi bahan ajar tahap II

Berdasarkan penilaian dan kritik saran dari ahli bahan ajar terhadap buku ini maka dapat dilakukan proses revisi produk dengan saran yang telah diberikan oleh validator. Adapun hasil validasi ini sebagai berikut: 
Tabel 4.4 Rekapitulasi Angket Validasi Ahli Bahan Ajar Tahap I

\begin{tabular}{llc}
\hline No & \multicolumn{1}{c}{ Aspek Penilaian } & Hasil Validasi \\
\hline 1 & Buku yang dikembangkan memuat petunjuk belajar & 3 \\
2 & Memuat CPMK dan Sub CPMK yang berlaku & 4 \\
3 & Mencantumkan tujuan pembelajaran & 4 \\
4 & Materi sesuai CPL yang dikembangkan & 4 \\
5 & Bahasa yang digunakan sesuai dengan usia mahasiswa & 3 \\
6 & Bahasa yang digunakan komunikatif & 3 \\
7 & Tampilan tek/font dapat dibaca dengan jelas & 4 \\
8 & Desain dampat menarik perhatian mahasiswa & 4 \\
9 & Adanya gambar yang mendukung proses penyerapan materi & 4 \\
10 & Terapat rangkuman dari seluruh materi yang ada & 4 \\
12 & Terdapat latihan soal yang bersifat menantang & 3 \\
& Skor Total & 44 \\
& Skor Maksimal & 48 \\
& Presentase & $91,6 \%$ \\
\hline
\end{tabular}

Berdasarkan hasil data diatas menunjukkan bahwa bahan ajar buku pada validasi tahap II diperoleh skor 91,6\% maka buku ini dapat dikatakan layak untuk dipakai. Menutut ahli buku ajar ini dikatakan bahwa buku yang dikembangkan dari sisi komponen sudah memuat petunjuk yang jelas, sesuai dengan sub CPMK, terdapat keelasan tujuan yang hendak dicapai, kegiatan sudah sesuai dengan tingkat usia mahasiswa, bahasa yang digunakan sudah tepat. Desain menarik mahasiswa, gambar sangat mendukung.

\section{b. Validasi Ahli Materi Buku}

Validasi bahan ajar terhadap ahli materi dilakukan dengan tujuan mengetahui tingkat kelayakan suatu materi yang diberikan dalam Buku ini. Materi yang dikembangkan didalam buku ini adalah Pembelajaran Matematika . Validasi bahan ajar berupa buku dinilai dari beberapa aspek yaitu: kesesuaian tujuan, kelayakan isi, kelayakan bahasa. Adapun hasil yang diperoleh adalaha sebagai berikut:

\begin{tabular}{llc}
\hline No & \multicolumn{1}{c}{ Aspek Penilaian } & Hasil Validasi \\
\hline & Kesesuaian Tujuan & 4 \\
2 & Materi yang disajikan sudah sesuai dengan dengan Sub CPMK & 3 \\
3 & Materi yang disajikan telah sesuai dengan indikator yang ada & 3 \\
& Indikator dalam mengemas materi pembelajaran terlihat jelas & \\
& Kelayakan isi & 3 \\
1 & Materi telah mendukung adanya Sub CPMK yang ada & 3 \\
2 & Materi telah mendukung adanya indikator yang ada & 3 \\
3 & Materi dalam buku memberikan konsep yang benar & 3 \\
4 & Keterkaitan antar mata pelajaran tak terlihat & 3 \\
5 & Materi yang diberikan dekat dengan kehidupan sehari-hari anak & 3 \\
6 & Jumlah latihan cukup dan sesuai materi & \\
& & 3 \\
& Kelayakan bahasa dan tulisan & 4 \\
2 & Penggunaan bahasa dalam bukutelah sesuai EYD & 3 \\
3 & Bahasa yang digunakan sangat mudah dipahami & 3 \\
4 & Menggunakan bahasa yang interaktif terhadap mahasiswa & 41 \\
& Penggunaan bahasa sesuai tingkatan/usia mahasiswa & 52 \\
& Skor Total & $78,8 \%$ \\
\hline
\end{tabular}




\section{c. Uji Coba Skala Kecil}

Uji coba skala kecil dilakukan setelah proses validasi selesai. Ini pada tanggal 14 September 2018 di kelas A. Subjek Ujicoba adalah mahasiswa kelas A dengan jumlah mahasiswa 43. Pada saat uji coba dosen berperan sebagai dosen model yang mengajar dengan menggunakan buku. Uji coba ini skala kecil ini dilakukan untuk mengetahui sejauh mana dosen mampu menggunakan buku dan dari mahasiswa bagaimana mereka memahami materi.

Dari hasil ujicoba diperoleh data yang bersumber dari pengamatan, hasil angket mahasiswa dan dosen. Pada saat uji coba kelompok kecil ini diperoleh data sebagai berikut:

\begin{tabular}{clcccc}
\hline No & \multicolumn{1}{c}{ Aspek Penilaian } & TS & KS & S & SS \\
\hline 1 & Kemudahan Memahami Materi belajar menggunakan buku & 0 & 7 & 30 & 6 \\
\hline 2 & Mahasiswa tidak mengalami kesulitan dalam penggunaan buku & 0 & 17 & 19 & 7 \\
\hline 3 & Tulisan atau teks yang ada di buku mudah terbaca & 0 & 5 & 31 & 7 \\
\hline 4 & Soal yang ada mudah untuk dikerjakan & 0 & 4 & 11 & 6 \\
\hline 5 & Anak-anak merasa senang ketika belajar menggunkan buku & 0 & 7 & 26 & 10 \\
\hline 6 & Anak-anak penasaran ketika melihat tampilan buku & 1 & 5 & 22 & 15 \\
\hline 7 & Mahasiswa merasa semangat belajar ketika menggunakan buku & 0 & 5 & 23 & 15 \\
\hline 8 & Anak-anak ingin belajar terus menggunakan buku meskipun jam & 0 & 12 & 25 & 6 \\
& belajar sudah berakhir & & & & \\
\hline 9 & $\begin{array}{l}\text { Mahasiswa mudah mengingat materi ketika dosen menggunakan } \\
\text { media buku }\end{array}$ & 0 & 7 & 20 & 16 \\
\hline 10 & Mahasiswa mengantuk ketika menggunakan di gibook & 24 & 14 & 4 & 1 \\
\hline 11 & Mahasiswa bosan belajar menggunakan buku & 34 & 9 & 0 & 0 \\
\hline 12 & Mahasiswa merasa rugi belajar menggunakan buku & 24 & 19 & 0 & 0 \\
\hline 13 & Mahasiswa aktif memperhatikan penjelasan dosen dalam pelajaran & 1 & 5 & 29 & 8 \\
\hline 14 & $\begin{array}{l}\text { Pembelajaran lebih menarik karena buku menyajikan berbagai teori } \\
\text { yang menyenangkan }\end{array}$ & 1 & 6 & 22 & 13 \\
\hline & Jumlah skor masing-masing & & & \\
\hline & Jumlah skor & & & & \\
& Skor Maksimal \\
Presentase & & $\mathbf{2 2 9 6}$ & \\
\hline
\end{tabular}

Berdasarkan tabel diatas terlihat bahwa respon mahasiswa ketika menggunakan buku dalam kategori baik. Hasil rekapitulasi menunjukkan bahwa 86,93\% mahasiswa memiliki respon positif. Hini terlihat dari beberapa indikator bahwa rata-rata dari setiap aspek penilaian 16-18 mahasiswa dari jumlah 43 mahasiswa merasa bahwa dalam belajar menggunakan buku mereka tidak mengalami kesulitan, tulisan yang ada pada teks menurut mereka mudah terbaca, mahasiswa sangat penasaran ketika diajar dengan buku, terlihat semangat belajar mereka juga sangat tinggi. Hasil angket ini juga didukung oleh hasil observasi melalui rekaman foto bahwa mahasiswa sangat ceria, dosen dapat membawa proses pembelajaran dengan santai, sesekali dosen mengajak mahasiswa untuk bercanda, dan di angket ketidakbosanan mereka ditunjukkan dari 43 orang yang tidak merasa ngantuk atau merasa rugi belajar adalah 14 mahasiswa.

Dikatakan juga bahwa respon mahasiswa ketika menggunakan buku sangat baik hal ini terlihat dari beberapa indikator bahwa 20-21 mahasiswa dari jumlah 43 mahasiswa merasa bahwa dalam belajar menggunakan buku mereka tidak mengalami kesulitan, tulisan yang ada pada teks menurut mereka mudah terbaca, mahasiswa sangat penasaran ketika diajar dengan buku, terlihat semangat belajar mereka juga sangat tinggi. Hasil angket ini juga didukung oleh hasil observasi melalui rekaman foto bahwa mahasiswa sangat ceria, dosen dapat membawa proses pembelajaran dengan santai, sesekali dosen mengajak mahasiswa untuk bercanda.

Pada tahap pembelajaran ini, mahasiswa diminta untuk mengamati video pembelajaran, kemudian dosen memberikan pertanyaan yang menantang bagi mahasiswa, Nampak bahwa mahasiswa sangat senang sekali mereka tidak merasa mengantuk atau bosan. Hal ini juga disampaikan beberapa mahasiswa mereka lebih senang langsung menerapkan isi dari materi yang ada dibuku yaitu tentang teori permainan. Ini menunjukkan bahwa belajar matematika yang sifatnya abstrak dapat dipelajari secara PAIKEM. 


\section{Pembahasan}

Dari hasil penelitian pengembangan ini diperoleh banyak temuan dari lapang yaitu tentang proses pembelajaran matematika dengan menggunakan bahan ajar pembelajaran matematika hasil produk pengembangan bukan dari refrensi Buku PJJ atau yang lain. Menurut penelitian ini ketika dilakukan validasi terhadap ahli bahan ajar dengan persentase 91,6\% yang menandakan bahwa bahan ajar ini layak digunakan dan sangat valid jika berdasar pada pembuatan komponen buku. Hal tersebut sesuai dengan proses dan langkah menurut teori dikans (2004:24) yang dikatakan bahwa dalam pembuatan buku ajar ini ada beberapa langkah yaitu dari komponen desain, daftar isi, kegiatan belajar mahasiswa, konsep materi benar, rangkuman materi, percobaan dan pelaporan.

Pada saat proses pembelajaran dengan menggunakan buku ditemukan bahwa mahasiswa sangat kondusif saat melakukan pengamatan, keaktifan terjalin sehingga aktivitas mahasiswa dalam kategori baik, dengan indikator $86,93 \%$ memiliki respon positif terhadap buku ajar yang telah dikembangkan. Berdasarkan hasil penelitian ini dapat disimpulkan bahwa penggunaan buku ajar pembelajaran matematika mempengaruhi aktivitas dan minat mahasiswa. Hal tersebut sesuai dengan pendapat Rusman (2012:323) bahwa pembelajaran akan lebih bermakna jika mahasiswa diberi kesempatan untuk berpartisi Matematikasi dalam berbagai aktivitas kegiatan pembelajaran, sehingga mahasiswa mampu mengaktualisasikan kemampuannya didalam dan diluar kelas.

Secara garis besar hasil penelitian pengembangan buku ajar ini dapat disimpulkan bahwa pengembangan buku ajar pembelajaran matematika ini memiliki kategori "Baik" oleh karena itu buku ini dikatakan layak sebagai bahan ajar baik dipelajari secara individu maupun dengan kelompok terbimbing. Pada hakikatnya suatu buku memiliki karakteristik self intruction yaitu membantu mahasiswa untuk belajar secara mandiri, self contained, memuat materi yang diperlukan dalam pembelajaran, stand alone tidak tergantung pada bahan ajar atau media lainnya, adaptif dengan perkembangan IPTEK, use friendly terkait penggunaan bahasa yang mudah dipahami oleh mahasiswa (Arum, Wahyudi.2016).

Pembelajaran menggunakan buku ajar pembelajaran matematika ini memiliki beberapa kelebihan : (1) Dalam buku ini ditetapkan tujuan pembelajaran yang jelas sehingga memberikan arah bagi mahasiswa untuk mencapai tujuan pembelajaran; (2) Buku ajar didesain menarik, tidak full teks tetapi untuk menyampaikan materi matematika yang abstrak banyak digunakan gambaran dari bendabenda konkrit sesuai karakteristik siswa sekolah dasar, (3) Buku yang bersifat menarik dan mudah untuk dipelajari serta menjawab kebutuhan mahasiswa tentunya meningkatkan minat belajar mahasiswa; (4) Buku ajar bersifat fleksibel karena materi dapat dipelajari oleh mahasiswa dengan kemampuan yang berbeda. Hal itu senada dengan yang disampaikan Lasmiyati (2014) yang menyatakan bahwa pengembangan modul dapat membantu mahasiswa belajar dengan baik karena memilikibeberapa kelebihan yaitu (1) Modul dapat memberikan umpan balik sehinga pembelajar mengetahui kekurangan mereka dan segera melakukan perbaikan; (2) tujuan yang tercantum pada modul akan memberikan arah yang jelas bagi pelaksanaan pembelajaran peserta didik;(3) Modul yang didesain menarik tentunya membuat peserta didik termotivasi untuk belajar; (4) Modul dapat dipelajari oleh semua peserta didikyang memiliki kemampuan berbeda-beda.

\section{SIMPULAN DAN SARAN}

Pada penelitian pengembangan buku pendamping pembelajaran matematika ini diperoleh kesimpulan bahwa : a) Hasil penelitian yang diperoleh yakni nilai validitas bahan ajar bernilai $91,6 \%$,begitu juga pada tahap uji validasi ahli materi mendapat skor $78,8 \%$, semua dalam kriteria valid. b) Mengenai keefektifan bahan ajar ditunjukkan dari respon positif yang diperoleh dari dosen dan mahasiswa sebagai pengguna produk. Setelah dilakukan revisi bahan ajar, nilai efektifitas bahan ajar pada tahap uji diperoleh hasil $86,93 \%$, ini dalam kriteria efektif. Dosen dan mahasiswa menyimpulkan bahwa bahan ajar berupa Buku efektif digunakan dalam pembelajaran

Dalam penelitian pengembangan ini memiliki beberapa kelemahan yang perlu diperhatikan, diantaranya Bahan ajar Buku hanya untuk mahasiswa yang memiliki intelegensi normal dan tinggi sehingga tidak sesuai jika diaplikasikan untuk kelas inklusi maka dari itu disarankan agar peneliti selanjutnya mengembangkan Buku untuk mahasiswa baik yang normal maupun berkebutuhan khusus. 
Pengembangan Bahan Ajar Pembelajaran Matematika Untuk Mahasiswa PGSD Semester 6 (Erna Yayuk)

\section{UCAPAN TERIMAKASIH}

Dengan mengucap puji syukur kehadirat Allah SWT, penulis menyampaikan rasa terima kasih yang sebesar-besarnya kepada seluruh pihak terutama Universitas Muhammadiyah Malang yang telah memberikan dukungan dalam bentuk pemberian dana, sehingga penelitian ini bisa berjalan dengan baik dan lancar. Mudah-mudahan apa yang kami tulis ini bisa memberikan manfaat bagi pembaca dan menginspirasi untuk terus berkarya dalam melakukan sebuah penelitian.

\section{DAFTAR PUSTAKA}

Amri, 2014. Pengembangan dan Model pembelajaran Matematika Integratif. Jakarta : PT Prestasi Pustakarya

Arum, T.S; Wahyudi.2016. Pengembangan Modul Pembelajaran tematik Integratif Subtema Hubungan Makhluk Hidup dalam Ekosistem pendekata Saintifik untuk Kelas 5 SD. Jurnal Scholaria. 6(3). 239-250.

A.M. Sardiman, 2007, Interaksi dan Motivasi Belajar Mengajar: Bandung, Rajawali PersA. M. Sardiman. 2001. Interaksi dan Motivasi Belajar Mengajar. Jakarta: Raja Grafindo Persada. 224 hlmn.

Creswell, John W. 2016. Research Design, pendekatan Kualitatif, Kuantitatif, dan Mixed. Yogyakarta: Pustaka Pelajar.

Eliyawati, Cucu. 2008. Media dan Sumber Belajar TK. Jakarta:Universitas Terbuka

Fatmawati, Laila,dkk. 2018. Pengembangan Modul Pendidikan Multikultural Berbasis Karakter Cinta Tanah Air dan Nasional pada Pembelajaran Tematik. SCHOLARIA Jurnal pendidikan dan Kebudayaan, (80-91)

Fawaid, Muhammad. 2015. Pengembangan Buku pendamping Dosen Berbasis Kurikulum 2013 Mata Pelajaran Matematika Kelas VII Semester I. Surabaya: Jurnal Pendidikan, Vol 1 Hal 43

Giri Putri, Ida Ayu dkk. 2013. Pengembangan Tes Matematika Berbasis SK/KD Dengan Teknik Concurent Pada Mahasiswa Kelas VI Di SD Negeri Se Kecamatan Gianyar. eJournal Program Pascasarjana Universitas Pendidikan Ganesha Program Studi Penelitian dan Evaluasi Pendidikan (Volum 3 Tahun 2013)

Hamalik, Oemar. 2001. Proses Belajar Mengajar. Jakarta : Bumi Aksara

Hakim Thursan, 2000, Belajar Secara efektif, Jakarta: Pupsa Swara.

Lasmiyati;Harta I. 2014. Pengembangan Modul Pembelajaran untuk Meningkatkan Pemahaman Konsep dan Minat SMP. Surakarta: Jurnal Pendidikan Matematika. 9 (2), 163.

Lestari, Ika.2013. Pengembangan Bahan Ajar Berbasis Kompetensi. Padang: Akadmia Permata.

Mafaat, Budi. 2010. Membumikan Matematika Dari Kampus Ke Kampung. Cirebon: Eduvision Publishing

Natawidjaja, Rochman. 2005. Konseling kelompok Konsep dasar dan Pendekatan, Bandung:Rizqi.

Nasution. 2004. Metode Research : Penelitian Ilmiah. Jakarta : Bumi Aksara.

Pramudita, W., \& Anugraheni, I. (2017). Studi Penguasaan Matematika Dan Bahasa Inggris Mahasiswa Program Studi Pendidikan Guru Sekolah Dasar (PGSD). Scholaria: Jurnal Pendidikan Dan Kebudayaan, 7(1), 70-82.

Suherman, E. 2003. Evaluasi Pembelajaran Matematika. Bandung: JICA UPI

Sugiyono. 2013. Metode Penelitian Pendidikan, Pendekatan Kuantitatif, Kualitatif, dan R\&D. Bandung: Alfabeta

Trianto, 2010. Mendesain Model Pembelajaran Inovatif-Progresif; Surabaya: Prenada Media Group. 